\title{
Regulation of bovine oviductal NO synthesis by follicular steroids and prostaglandins
}

\author{
Yoshihiko Kobayashi ${ }^{1}$, Yuki Yamamoto ${ }^{1}$, Soichi Kageyama², Hiroki Hirayama², \\ Koji Kimura ${ }^{1}$ and Kiyoshi Okuda ${ }^{1,3}$ \\ 'Laboratory of Reproductive Physiology, Graduate School of Environmental and Life Science, \\ Okayama University, Okayama, Japan, ${ }^{2}$ Animal Biotechnology Group, Animal Research Center, \\ Hokkaido Research Organization, Hokkaido, Japan and ${ }^{3}$ Obihiro University of Agriculture and \\ Veterinary Medicine, Hokkaido, Japan
}

Correspondence should be addressed to Kiyoshi Okuda; Email: kokuda@okayama-u.ac.jp

\begin{abstract}
Nitric oxide (NO) is a regulator of sperm motility, oocyte/embryo survival, and waves of contraction/relaxation in mammalian oviducts. As follicles control oviductal functions by two routes at least, (1) a systemic way via blood vessels before ovulation, (2) a direct way by entering of follicular fluid through fimbria at ovulation, we hypothesized that NO synthesis in the bovine oviduct is regulated by follicular steroids and prostaglandins (PGs). Quantification of mRNA expressions in the ampullary tissues showed that inducible NO synthase (NOS2) mRNA expression was highest on the day of ovulation (day 0). By contrast, NOS2 mRNA expression in the isthmus was highest on days 5-6 and lowest on days 19-21. Endothelial NOS (NOS3) mRNA expressions in either the ampulla or the isthmus did not change during the estrous cycle. PGE2 and PGF2 $\alpha$ increased NOS2 mRNA expressions in cultured ampullary oviductal epithelial cells after 1-h incubation. These increases were suppressed by an antagonist of E-prostanoid receptor type 2, one of the PGE2 receptor. Estradiol-17 $\beta$ decreased the expression of NOS2 mRNA expression in cultured isthmic epithelial cells $24 \mathrm{~h}$ after treatment. This effect was suppressed by an antagonist of estrogen receptor $\alpha$ (ESR1). Expression of ESR1 was highest on days 19-21 in the isthmic tissues. The overall findings indicate region-specific difference of NO synthesis in the oviduct. PGs flowed from ruptured follicle may up-regulate NO synthesis in the oviductal epithelium, whereas circulating E2 seems to inhibit NO synthesis via ESR1 in the isthmus at the follicular stage.

Reproduction (2016) 151 577-587
\end{abstract}

\section{Introduction}

In mammals, the oviduct is an essential organ for the transport of gametes and embryos (Menezo \& Guerin 1997, Suarez 2008). Ovulated cumulus-oocyte complexes (COCs) and sperms are transported to the ampulla of the oviduct where fertilization occurs (Ulbrich et al. 2010). Early embryos are transported to the uterus within a few days (Freeman et al. 1991). The transport of gametes and embryos is induced by alternate waves of contraction and relaxation of the oviductal smooth muscle and the ciliary beating of oviductal epithelial cells (Halbert et al. 1976, Hunter 2012). Various substances including nitric oxide (NO), ovarian steroids, and prostaglandins (PGs) regulate the waves of contraction and relaxation (Helm et al. 1982, Rosselli et al. 1994, Ekerhovd et al. 1997, 1999, Al-Alem et al. 2007).

Nitric oxide is a physiological mediator of numerous cellular and organ functions (Ignarro et al. 2001). It is synthesized from L-arginine by NO synthases (NOSs).
Nitric oxide synthases have three isoforms, neuronal NOS (nNOS), inducible NOS (NOS2), and endothelial NOS (NOS3) (Ulbrich et al. 2006). Nitric oxide relaxes the oviductal smooth muscle for gamete/embryo transport (Rosselli et al. 1994, Yilmaz et al. 2012). In addition, NO has crucial roles in gamete/embryo activity and survivability. NO stimulates the motility of spermatozoa (Miraglia et al. 2011), and the inhibition of NO synthesis increases the mortality of early embryos in mice (Gouge et al. 1998).

Each oviductal region has various specific functions. The ampulla transports the ovulated oocytes to the site of fertilization and supports fertilization (Hunter 2012). The isthmus promotes embryo development by secreting various molecules and transports embryos to the uterus by smooth muscle activity (Hunter 2012). To perform these functions, the oviductal regions are morphologically different. For example, the proportion of two types of epithelial cells, ciliated cells and secretory 
cells, is different among regions of the bovine oviduct (Kölle et al. 2009). In the murine oviduct, the ampullary region has high ciliary activity, whereas the isthmus has strong muscular contraction and weak ciliary activity (Noreikat et al. 2012) The expressions of genes for endothelins, PG synthases, and sex steroid receptors are also different among regions of the oviduct (Ulbrich et al. 2003, Gauvreau et al. 2010, Jeoung et al. 2010, SaintDizier et al. 2012). Similarly, NOS2 mRNA expression at the day of ovulation is higher in the ampulla than in the isthmus of the bovine oviduct (Ulbrich et al. 2006). Thus, NO synthesis may be regulated differently in the ampulla and isthmus.

Ovarian steroids are major molecules controlling oviductal functions (Wijayagunawardane et al. 1999, Ulbrich et al. 2003, Szóstek et al. 2011). During the estrous cycle except at ovulation, these steroids participate in oviductal physiological events via systemic way. The highest levels of estrogen in circulation and oviductal tissue at the follicular phase (Wijayagunawardane et al. 1998, Acosta et al. 2003) support that idea. At ovulation, follicular fluid with COC enters the oviduct through fimbria, the entrance of the oviduct. As follicular fluid contains high concentrations of PGE2, PGF2 $\alpha$, and ovarian steroids (Acosta et al. $1998,2000)$, these molecules are possible to influence oviductal milieu.

In this study, we hypothesized that molecules derived from follicles participate oviductal NO synthesis via two distinct routes: (1) a systemic way via blood vessels during the estrous cycle and (2) a direct way through fimbria only at ovulation. To test the above hypothesis, we determined (1) cyclic changes of NOSs and receptors for estrogen (ESRs), progesterone (PGR), PGE (PTGERs), and PGF (PTGFR) expressions in bovine ampullary and isthmic oviductal tissues during the estrous cycle and (2) the effects of exogenous E2, P4, PGE2, and PGF2 $\alpha$ on NO synthesis in cultured ampullary and isthmic oviductal epithelial cells.

\section{Materials and methods}

\section{Experimental design}

Expressions of NOSs in oviductal tissues

Changes in mRNA expressions of NOS2 and NOS3 in oviductal tissues during the estrous cycle were determined to clarify ovarian stage-specific regulation of $\mathrm{NO}$ synthesis in the oviduct. Immunohistochemical investigations of NOS proteins were performed to clarify which types of oviductal cells (epithelial, stromal, or smooth muscle cells) express those proteins.

\section{Expressions of ESRs, PGR, PTGERs, and PTGFR in oviductal tissues}

Changes in mRNA expressions of ESRs, PGR, PTGERs, and $P T G F R$ and protein distributions in oviductal tissues were investigated to clarify when the ligands of those receptors affect oviductal physiology and which types of oviductal cells receive those ligands to regulate $\mathrm{NO}$ synthesis.

Concentrations of ovarian steroids and prostaglandins (PGs) in follicular fluid immediately before ovulation

To determine appropriate concentrations of estradiol-17 $\beta$ (E2), progesterone (P4), PGE2, and PGF2 $\alpha$ in the following experiments using cultured oviductal epithelial cells, we measured the concentrations of those molecules in follicular fluid obtained from cows that were treated to induce superovulation.

Effects of E2 or P4 on NOS2 mRNA expression in cultured oviductal epithelial cells

To clarify whether ovarian steroids affect NO synthesis in the oviduct, cultured oviductal epithelial cells isolated from the ampulla and isthmus were incubated with E2 or P4. Concentrations of E2 $(0.1,1,10 \mathrm{nmol} / \mathrm{L})$ and P4 (1, 10, $100 \mathrm{nmol} / \mathrm{L})$ were referenced by concentrations in follicular fluid (Table 1) and in circulation (Kaneko 1995). Additionally, antagonist of ESR1 or ESR2 was incubated in combination with E2 in cultured isthmic epithelial cells to determine which types of estrogen receptors regulate NOS2 expression.

\section{Effects of PGs on NOS2 mRNA expression in cultured oviductal epithelial cells}

To determine the roles of prostaglandins contained in follicular fluid after ovulation, cultured oviductal epithelial cells isolated from the ampulla and isthmus were incubated with PGE2 or PGF2 $\alpha$. Concentrations of PGE2 and PGF2 $\alpha(0.01,0.1,1 \mu \mathrm{mol} / \mathrm{L})$ were referenced by concentrations in follicular fluid (Table 1 and previous reports (Acosta et al. 1998, 2000)). Additionally, an antagonist of E-prostanoid receptor type 2 (PTGER2) or PTGER4 was added in combination with PGE2 in cultured ampullary epithelial cells to determine which types of PGE2 receptors regulate NOS2 expression. As PTGER1 receptor is not expressed and the expression level of PTGER3 receptor is lower than that of PTGER2 and PTGER4 in the bovine oviduct (Gabler et al. 2008), either effects of an antagonist of PTGER1 or PTGER3 on NOS2 mRNA expression was not investigated in this study.

\section{Differential expression of NOS2 mRNA between the ampulla} and isthmus

To investigate the difference of capability for NO synthesis between the ampulla and isthmus, NOS 2 mRNA expressions in oviductal tissues and cultured epithelial cells were compared between the ampulla and isthmus.

Table 1 Concentrations of estradiol-17 $\beta$ (E2), progesterone (P4), prostaglandin E2 (PGE2), and PGF2 $\alpha$ in follicular fluid obtained from cows that were treated with super-ovulation. Follicular fluid was collected 26-27 h after administering a GNRH analog.

\begin{tabular}{lc}
\hline Hormone & Concentration $(\mathrm{nmol} / \mathrm{L})$ \\
\hline E2 & $106.3-409.9$ \\
P4 & $771-2763$ \\
PGE2 & $5.68-40.1$ \\
PGF2 $\alpha$ & $61.9-835$ \\
\hline
\end{tabular}




\section{Collection of bovine oviducts}

Oviducts of Holstein cows were collected at a local abattoir within 10-20 min after the exsanguination. The stages of the estrous cycle were determined based on a macroscopic observation of the ovary and the uterus (Okuda et al. 1988, Miyamoto et al. 2000). After trimming of the oviducts being ipsilateral to the corpus luteum, the ampullary and the isthmic sections were immediately frozen and stored at $-80^{\circ} \mathrm{C}$ until mRNA and protein extraction. Oviductal tissues for immunohistochemistry were fixed in PBS with 10\% (v/v) neutral formaldehyde for $24 \mathrm{~h}$ and then embedded in paraffin. For cell culture, the oviducts were submerged in ice-cold saline and transported to the laboratory.

\section{Determination of PG concentrations in collected follicular fluid}

A Japanese black cow and an Angus cow were utilized for superovulation treatment and collecting follicular fluids. A total of 20 Arrmour units (AU) of follicle-stimulating hormone (FSH; Antorin R-10; Kyoritsu Seiyaku Corporation, Kanagawa, Japan) were administered twice daily in decreasing doses during 3 days $(5,5,3,3,2$ and 2 AU respectively). A PGF2 $\alpha$ analog (cloprostenol, Resipron-C; ASKA Pharmaceutical Co., Tokyo, Japan, $0.5 \mathrm{mg}$ ) was administered on the third day of FSH administration. Cows had a controlled internal drug release device (CIDR) (CIDR1900; Pfizer Japan Inc., Tokyo, Japan) inserted for 8-9 days until the injection of the PGF2 $\alpha$ analog and were received estradiol benzoate (Kyoritsu Seiyaku Corporation, $1 \mathrm{mg}$ ) 4 days before the first FSH administration. These cows were injected with a GNRH analog (fertirelin acetate; Conceral, Nagase Pharmaceutical, Tokyo, Japan, $100 \mu \mathrm{g}$ ) $24 \mathrm{~h}$ after CIDR removal. Transvaginal collection of follicular fluids was carried out at 26-27 h after GNRH administration. Follicular aspiration was conducted using an ultrasound scanner (SSD-900; ALOKA, Tokyo, Japan) and 7.5 MHz convex array transducer (UST-9106P-7.5; ALOKA) attached with a 17 -gauge stainless steel needle guide. Follicles over $8 \mathrm{~mm}$ in diameter were aspirated by an aspirator (FV4; FHK, Tokyo, Japan) equipped with a disposable aspiration needle (Misawa Medical Industry Co., Ltd. Ibaraki, Japan). Collected follicular fluids were centrifuged $\left(1800 \mathrm{~g}, 10 \mathrm{~min}, 4^{\circ} \mathrm{C}\right)$ and supernatants were stored at $-20^{\circ} \mathrm{C}$ until measuring concentrations of PGs. All procedures with animal subjects had been reviewed and approved by the Animal Care Committee of the Animal Research Center, Hokkaido Research Organization.

The concentrations of PGE2 in the collected follicular fluids were determined by enzyme immunoassay as described previously (Tanikawa et al. 2005). The PGE2 standard curve ranged from 0.039 to $10 \mathrm{ng} / \mathrm{mL}$, and the ED50 of the assay was $0.625 \mathrm{ng} / \mathrm{mL}$. The intra-assay coefficients of variation were on average $2.6 \%$. The range of the concentrations of PGE2 in follicular fluids was $0.006-0.04 \mu \mathrm{mol} / \mathrm{L}$.

The concentrations of PGF $2 \alpha$ in the collected follicular fluids were determined by enzyme immunoassay as described previously (Uenoyama et al. 1997) with our modification using peroxidase-labeled PGF2 $\alpha$ as a tracer (1:25,000 final dilution) and anti-PGF2 $\alpha$ serum (1:100,000 final dilution). The
anti-PGF2 $\alpha$ serum (OK-PGF) was produced by Sigma-Aldrich. Cross-reactivities of the anti-PGF2 $\alpha$ serum were validated by comparingtheinhibition ofbinding ofperoxidase-labeledPGF $2 \alpha$ to antiserum: PGF2 $\alpha, 100 \%$; PGA2, $0.38 \%$; PGD2, $2.51 \%$; PGE1, 0.53\%; PGE2, 0.08\%; PGF1 $\alpha, 5.62 \%$; PGF2 $\alpha \beta, 0.49 \%$; and PGF2 $\beta, 0.58 \%$. The PGF2 $\alpha$ standard curve ranged from 0.016 to $4 \mathrm{ng} / \mathrm{mL}$, and the ED50 of the assay was $0.25 \mathrm{ng} / \mathrm{mL}$. The intra-assay coefficients of variation were on average $3.9 \%$. The range of the concentrations of PGF $2 \alpha$ in follicular fluids was $0.06-0.83 \mu \mathrm{mol} / \mathrm{L}$. This assay system of PGF $2 \alpha$ has no cross-reaction with cloprostenol, a PGF $2 \alpha$ analog. In this study, cloprostenol was utilized for luteolysis $50-51 \mathrm{~h}$ before collection of follicular fluid. The half-life of cloprostenol was approximately $3 \mathrm{~h}$ and ${ }^{14} \mathrm{C}$-labeled cloprostenol was not detected in the ovary $48 \mathrm{~h}$ after dose of the PGF2 $\alpha$ analog (Reeves 1978). Thus, we considered the concentration of PGF2 $\alpha$, which we detected in follicular fluid did not contain exogenous PGF2 $\alpha$.

\section{Isolation and culture of oviductal cells}

Epithelial cells were enzymatically isolated from the ampullary and the isthmic sections of the oviduct at peri-ovulatory phase as described previously (Kobayashi et al. 2013). The isolated cells were purified by using two different concentrations of trypsin (Kobayashi et al. 2013). All the purified cells were determined to be epithelial cells (no contamination of stromal cells) by immunocytochemistry (Kobayashi et al. 2013). The purified cells were seeded onto 48-well plates (677180; Greiner Bio-One, Frickenhausen, Germany) or $25 \mathrm{~cm}^{2}$ culture flasks (690175; Greiner Bio-One). The plates and flasks for epithelial cells were coated with collagen obtained from mouse tails. The cells were cultured at $38.5^{\circ} \mathrm{C}$ in a humidified atmosphere of $5 \% \mathrm{CO}_{2}$ in air. The medium was exchanged every $48 \mathrm{~h}$ until the cells reached confluency. When the cells reached 90-95\% confluency (10-11 days after the isolation of the cells), they were used for experiments.

\section{Cell treatment}

Oviductal epithelial cells that reached confluency were incubated with estradiol-17 $\beta$ (E2, 0.1, 1, and $10 \mathrm{nmol} / \mathrm{L}$, E8875; Sigma-Aldrich), progesterone (P4, 1, 10, and $100 \mathrm{nmol} / \mathrm{L}$, P8783; Sigma-Aldrich), prostaglandin E2 (PGE2, 0.01, 0.1, and $1 \mu \mathrm{mol} / \mathrm{L}, 14010$; Cayman Chemical), and PGF2 $\alpha$ (0.01, 0.1, and $1 \mu \mathrm{mol} / \mathrm{L} ; 16010$, Cayman Chemical) in phenol red-free DMEM/F-12 Ham (D2906; Sigma-Aldrich) supplemented with $500 \mu \mathrm{mol} / \mathrm{L}$ ascorbic acid (013-12061; Wako Pure Chemical Industries), $5 \mu \mathrm{g} / \mathrm{mL}$ holo-transferrin (T4132; Sigma-Aldrich), $5 \mathrm{ng} / \mathrm{mL}$ sodium selenite (S5261; Sigma-Aldrich), $2 \mu \mathrm{g} / \mathrm{mL}$ insulin (14011; Sigma-Aldrich), $0.1 \%(\mathrm{w} / \mathrm{v})$ bovine serum albumin (A7888; Sigma-Aldrich), and $20 \mathrm{mg} / \mathrm{mL}$ gentamicin (G1397; Sigma-Aldrich) for 1,4 , and $24 \mathrm{~h}$ at $38.5^{\circ} \mathrm{C}$. Selective antagonists of estrogen receptors (ESRs) were co-incubated with E2 $(10 \mathrm{nmol} / \mathrm{L})$. MPP dihydrochloride $(100 \mathrm{nmol} / \mathrm{L}$, M7068; Sigma-Aldrich) for ESR1 and PHTPP (100 nmol/L, 2662; R\&D Systems) for ESR2 were used as selective antagonists. MPP dihydrochloride has been demonstrated to be a selective antagonist for ESR1 (Sun et al. 2002) and PHTPP 

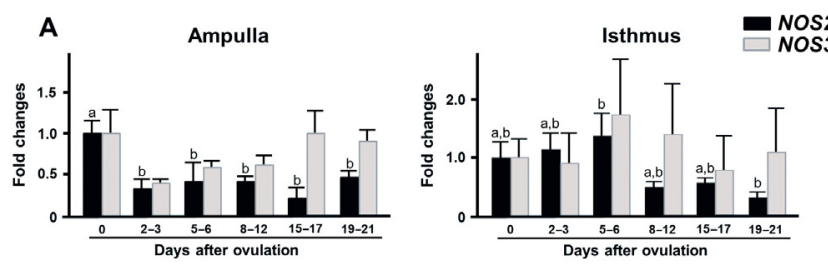

B
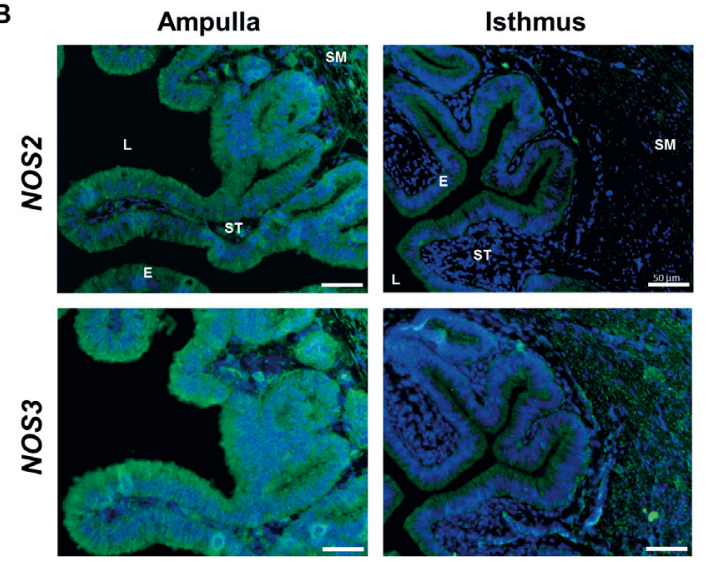

Figure 1 (A) Cyclic changes of NOS2 and NOS3 mRNA expressions in tissues collected from the ampulla and isthmus of the bovine oviduct (mean \pm S.E.M., $n=5$ oviducts). Significance of differences was assessed by the analysis of variance (ANOVA) followed by Tukey-Kramer test for multiple comparisons. Different superscript letters indicate significant differences $(P<0.05)$.

(B) Immunohistochemical analysis of NOS protein distributions in the ampulla and isthmus of the oviduct obtained from cows at the day of ovulation (L: lumen, E: epithelium, ST: stroma, SM: smooth muscle). Green color (Alexa 488) indicates each target protein (NOS2 or NOS3), and blue color (DAPI) indicates nuclei of the cells. Scale is the same in all the photomicrographs.

is known to display 36-fold selectivity for ESR2 than ESR1 (Compton et al. 2004). Antagonists of PTGER2 or PTGER4 were incubated in combination with PGE2 $(1 \mu \mathrm{mol} / \mathrm{L})$ in cultured ampullary epithelial cells. AH6809 and AH23848 are selective antagonists for PTGER2 and PTGER4, respectively (Coleman et al. 1994, Woodward et al. 1995). All the antagonists were pre-incubated with the cells for $1 \mathrm{~h}$ before incubation with each ligand. After incubations, supernatants were collected for measuring $\mathrm{NO}$ concentration and the cells were collected to measure DNA content for standardizing the NO concentration. Total RNA of the cells was extracted from another culture plate for the determination of mRNA expressions.

\section{Total RNA extraction and quantitative RT-PCR}

Total RNA was extracted from oviductal tissues and cells using TRIsure according to the manufacturer's directions. Using iScript RT Supermix for RT-qPCR (170-8841; Bio-Rad Laboratories), $1 \mu \mathrm{g}$ of each total RNA was reverse transcribed. Quantifications of mRNA expressions were determined by Quantitative RT-PCR using MyiQ (Bio-Rad Laboratories) and SooAdvanced SYBR Green
A

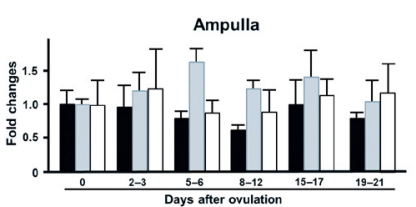

B

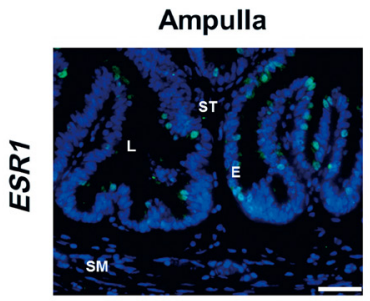

Ampulla
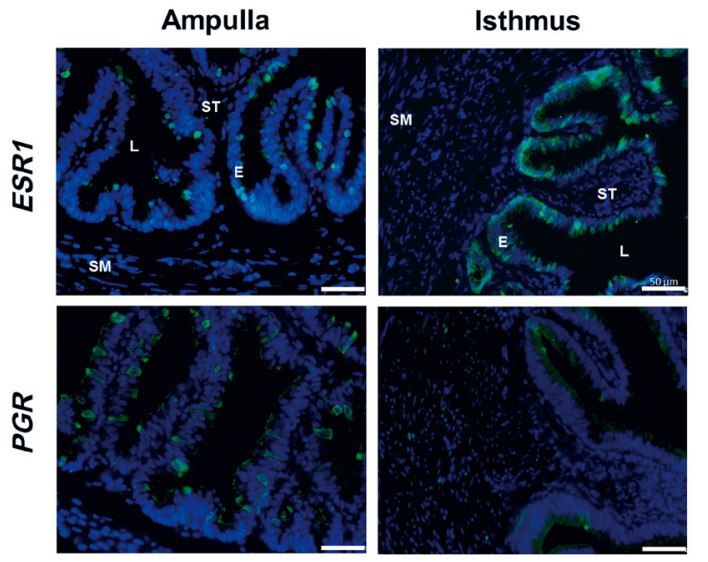

Figure 2 (A) Cyclic changes of estrogen receptor $\alpha(E S R 1), E S R 2$, and progesterone receptor $(P G R)$ mRNA expressions in tissues collected from the ampulla and isthmus of the bovine oviduct (mean \pm S.E.M., $n=5$ oviducts). Significance of differences was assessed by the analysis of variance (ANOVA) followed by Tukey-Kramer test for multiple comparisons. Different superscript letters indicate significant differences $(P<0.05)$. (B) Immunohistochemical analysis of ESR1 and PGR protein distributions in the ampulla and isthmus of the oviduct obtained from cows at follicular stage (L: lumen, E: epithelium, ST: stroma, SM: smooth muscle). Green color (Alexa 488) indicates each target protein (ESR1 or PGR), and blue color (DAPI) indicates nuclei of the cells. Scale is the same in all the photomicrographs.

Supermix (1725261B10; Bio-Rad Laboratories) starting with 4 ng reverse-transcribed total RNA as described previously (Sakumoto et al. 2006). All primers were designed to amplify specific products for NOS2 (forward: 5'-TAC CCT CAG TTC TGC GCT TT-3'; reverse: 5'-GGG ATC TCA ATG TGG TGC TT-3'), NOS3 (forward: 5'-AGG CTC TCA CCT TCT TCC TG-3'; reverse: 5'-AAC CAC TTC CAC TCC TCG TA-3'), ESR1 (forward: 5'-CAG GCA CAT GAG CAA CAA AG-3'; reverse: 5'-TCC AGC AGC AGG TCG TAG AG-3'), and ESR2 (forward: 5'-CTG AAG CAT GAA CTC CAG CAC-3'; reverse: 5'-CAG GAA GGA CCA CAT AGC AGA$\left.3^{\prime}\right)$. The specificity of each primer set was confirmed by running the PCR products on a $2.0 \%$ agarose gel. Protocol conditions were consisted of denaturation at $95^{\circ} \mathrm{C}$ for $30 \mathrm{~s}$, followed by 45 cycles at $95^{\circ} \mathrm{C}$ for $6 \mathrm{~s}, 60^{\circ} \mathrm{C}$ for $6 \mathrm{~s}$, and $72^{\circ} \mathrm{C}$ for $6 \mathrm{~s}$ with a final dissociation (melting) curve analysis. To standardize the relative level of expression of each mRNA, three potential housekeeping genes, $\beta$-actin (ACTB; forward: 5'-CAG CAA GCA GGA GTA CGA TG-3'; reverse: $5^{\prime}$-AGC CAT GCC AAT CTC ATC TC-3'), $18 \mathrm{~S}$ ribosomal RNA (18S rRNA; forward: 5'-TCG CGG AAG GAT TTA AAG TG-3'; reverse: 5'-AAA CGG CTA CCA CAT CCA AG-3'), and glyceraldehyde-3-phosphate dehydrogenase (GAPDH forward: 5'-CAC CCT CAA GAT TGT CAG CA-3'; 

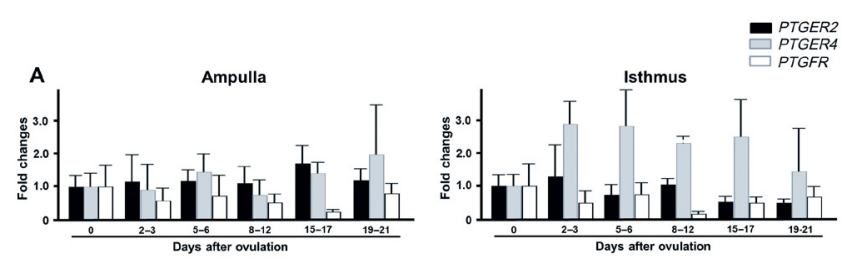

B
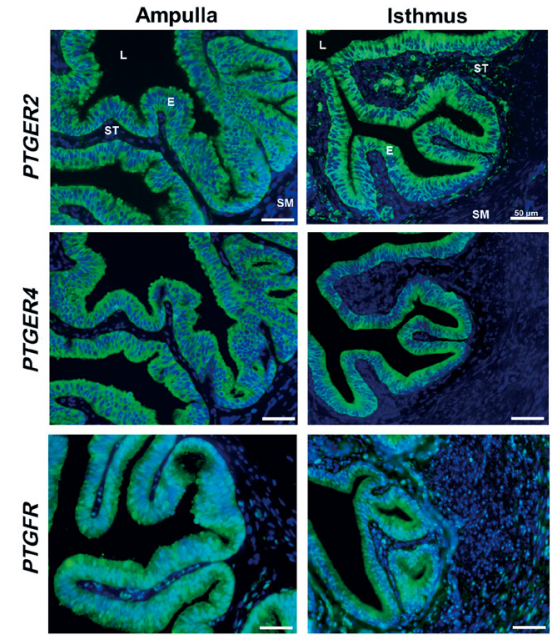

Figure 3 (A) Cyclic changes of E-prostanoid receptor 2 (PTGER2), PTGER4, and F-prostanoid receptor (PTGFR) mRNA expressions in tissues collected from the ampulla and isthmus of the bovine oviduct (mean \pm S.E.M., $n=5$ oviducts). Significance of differences was assessed by the analysis of variance (ANOVA) followed by Tukey-Kramer test for multiple comparisons. There were no significant differences $(P>0.05)$. (B) Immunohistochemical analysis of PTGER and PTGFR protein distributions in the ampulla and isthmus of the oviduct obtained from cows at the day of ovulation (L: lumen, E: epithelium, ST: stroma, SM: smooth muscle). Green color (Alexa 488) indicates each target protein (PTGER2, PTGER4, or PTGFR), and blue color (DAPI) indicates nuclei of the cells. Scale is the same in all the photomicrographs.

reverse: 5'-GGT CAT AAGTCC CTC CAC GA-3') were initially tested. GAPDH was found to be the most stable of the three genes by Normfinder software (http://moma.dk/normfindersoftware), and so GAPDH transcripts were selected as the internal control in our experiments. Amplification efficiencies of all the primers were checked by the determination of $\mathrm{Ct}$ values for a dilution series of the target template. Efficiencies of all the primers were 95-100\%. The relative level of expression of each mRNA was measured using the $2^{-\Delta \Delta C T}$ method (Livak \& Schmittgen 2001).

\section{Immunohistochemistry}

Sections $(6 \mu \mathrm{m})$ were deparaffinized and rehydrated in a graded series of ethanol and washed in tap water. Antigens were retrieved by using microwave in Tris-EDTA buffer $(\mathrm{pH}$ 9.0, for NOS2, NOS3, and PGR) or in $0.01 \mathrm{mo} / \mathrm{L}$ citrate buffer ( $\mathrm{pH}$ 6.0, the other antigens) for $15 \mathrm{~min}$ at $600 \mathrm{~W}$. Nonspecific binding was blocked in $2.5 \%$ horse serum (S-2012; Vector Laboratories) for $20 \mathrm{~min}$ at room temperature. The sections were incubated with specific primary antibodies for NOS2 (160862;
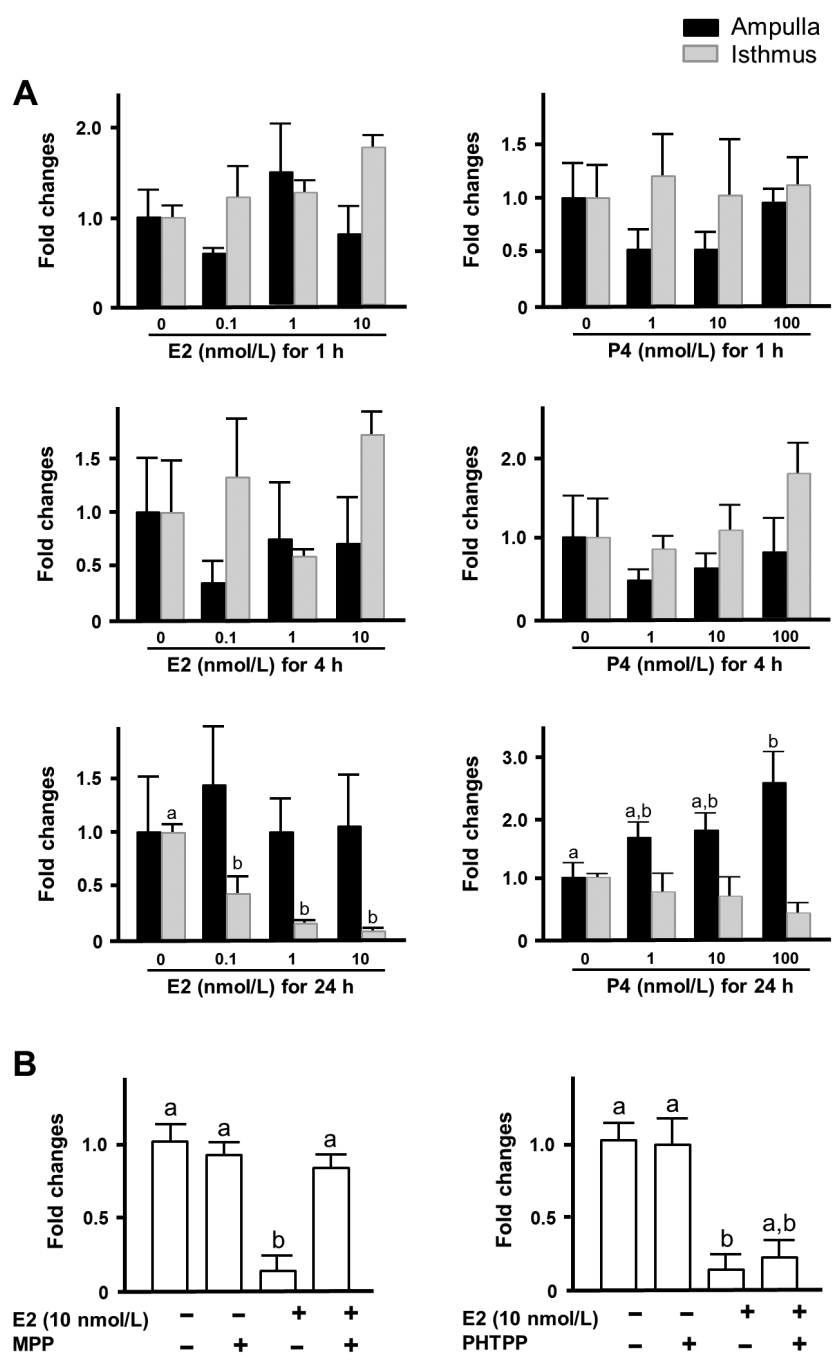

Figure 4 (A) Effects of estradiol-17 $\beta$ (E2) or progesterone (P4) on NOS2 mRNA expression in the oviductal epithelial cells isolated from the ampulla (black bar) and isthmus (gray bar) of the oviduct (mean \pm S.E.M., $n=8$ oviducts, $n=12$ only in the incubation with P4 for $24 \mathrm{~h}$ ). Significance of differences was assessed by the analysis of variance (ANOVA) followed by Tukey-Kramer test for multiple comparisons. Different superscript letters indicate significant differences $(P<0.05)$. (B) Effects of selective antagonists of each ESR on NOS2 mRNA expression in isthmic oviductal epithelial cells (mean \pm S.E.M., $n=8$ oviducts). MPP dihydrochloride (ESR1 antagonist) or PHTPP (ESR2 antagonist) was CO-incubated with E2 $(10 \mathrm{nmol} / \mathrm{L})$ for $24 \mathrm{~h}$. Significance of differences was assessed by the analysis of variance (ANOVA) followed by Tukey-Kramer test for multiple comparisons. Different superscript letters indicate significant differences $(P<0.05)$.

Cayman Chemical), NOS3 (160880; Cayman Chemical), ESR1 (SAB2100712; Sigma-Aldrich), PGR (SAB4502185; SigmaAldrich), PTGER2 (ab167171; Abcam), PTGER4 (ab133170; Abcam), or PTGFR (101802; Cayman Chemical) overnight at $4^{\circ} \mathrm{C}$, washed with PBS three times, and incubated with secondary antibody for rabbit-lgG conjugated with Alexa 488 (21206; Life Technologies) for $1 \mathrm{~h}$ at room temperature, washed with PBS three times, covered with ProLong Gold Antifade 

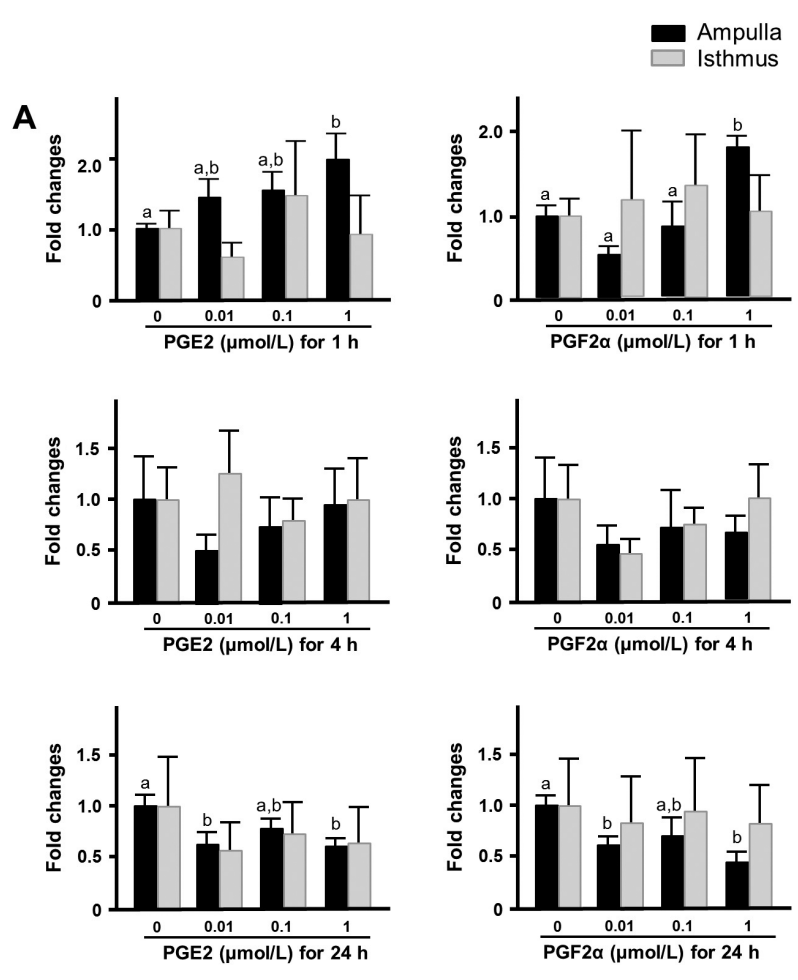

B
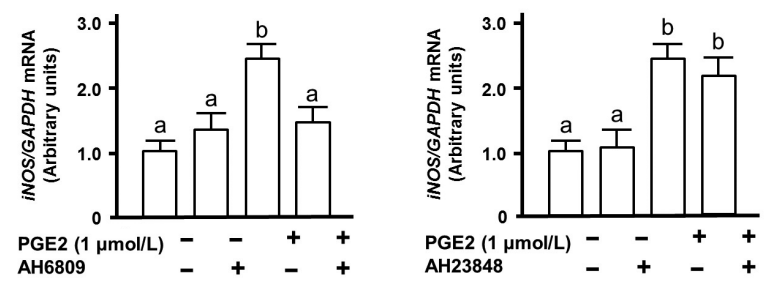

Figure 5 (A) Effects of prostaglandin (PG) E2 and PGF2 $\alpha$ on NOS2 mRNA expression in ampullary and isthmic oviductal epithelial cells (mean \pm S.E.M., $n=5$ oviducts). Significance of differences was assessed by the analysis of variance (ANOVA) followed by TukeyKramer test for multiple comparisons. Different superscript letters indicate significant differences $(P<0.05)$. (B) Effects of selective antagonists of each PTGER on NOS2 mRNA expression in isthmic oviductal epithelial cells (mean \pm S.E.M., $n=7$ oviducts). AH6809 (PTGER2 antagonist) or AH23848 (PTGER4 antagonist) was co-incubated with PGE2 $(1 \mu \mathrm{mol} / \mathrm{L})$ for $1 \mathrm{~h}$. Significance of differences was assessed by the analysis of variance (ANOVA) followed by Tukey-Kramer test for multiple comparisons. Different superscript letters indicate significant differences $(P<0.05)$.

Reagent with DAPI (36935; Life Technologies), and observed under a fluorescence microscope (FSX100; Olympus).

\section{Statistical analysis}

All experimental data are expressed as the mean \pm S.E.M. The statistical significance of differences was assessed by analysis of variance (ANOVA) followed by Tukey-Kramer test for multiple comparisons using GraphPad Prism (GraphPad Software). $P$ values less than 0.05 were considered to be statistically significant.

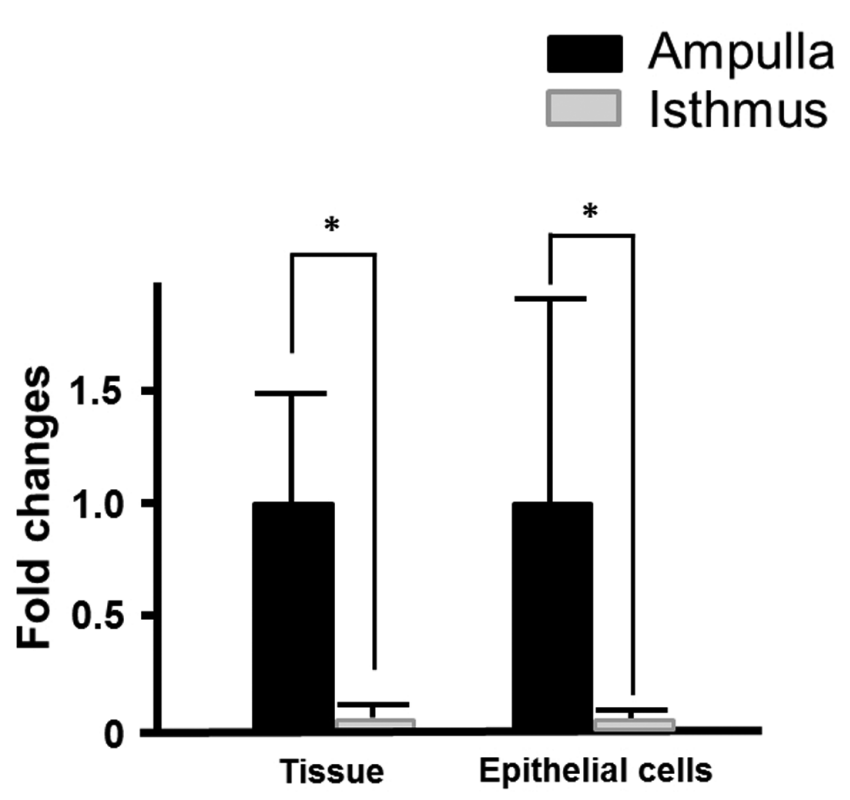

Figure 6 Differential expression of NOS2 mRNA between the ampulla and isthmus in oviductal tissues (A, $n=6$, mean \pm S.E.M.) and cultured epithelial cells (B, $n=5$, mean \pm S.E.M.). Significance of differences was assessed by the analysis of variance (ANOVA) followed by Student's $t$-test. Asterisks indicate significant differences $(P<0.05)$.

\section{Results}

\section{Expressions of NOSs in oviductal tissues}

NOS2 mRNA expression in the ampulla was highest at the day of ovulation (day 0) (Fig. 1A, $P<0.05$ ). In the isthmus, NOS2 mRNA expression was highest at days 5-6 and gradually decreased toward the follicular phase. NOS2 expression in the isthmus was lowest at days 19-21 (Fig. 1A, $P<0.05$ ). However, NOS3 expressions in both segments did not significantly change during the estrous cycle. NOS2 and NOS3 proteins were immunohistochemically detected in epithelial, stromal, and smooth muscle layers of the ampullary region (Fig. 1B). In the isthmus, NOS3 was expressed in the epithelium, stroma, and smooth muscle. NOS2 was clearly detected in epithelium, but only weakly detected in stroma and smooth muscle. Activity of NO synthesis by NOS2 is well known to be extremely higher than by NOS3 (Moncada \& Higgs 1993). As NOS3 expression did not change during the estrous cycle in this study, only NOS2 expression was investigated in the following experiments.

\section{Expressions of ESRs, PGR, PTGERs, and PTGFR}

ESR 1 mRNA expression was highest at days 19-21 (follicular phase) in isthmic oviductal tissues, whereas the expression of ESR1 mRNA did not change in ampullary tissues during estrous cycle (Fig. 2A). The mRNAs of other steroid and PG receptors were stably 


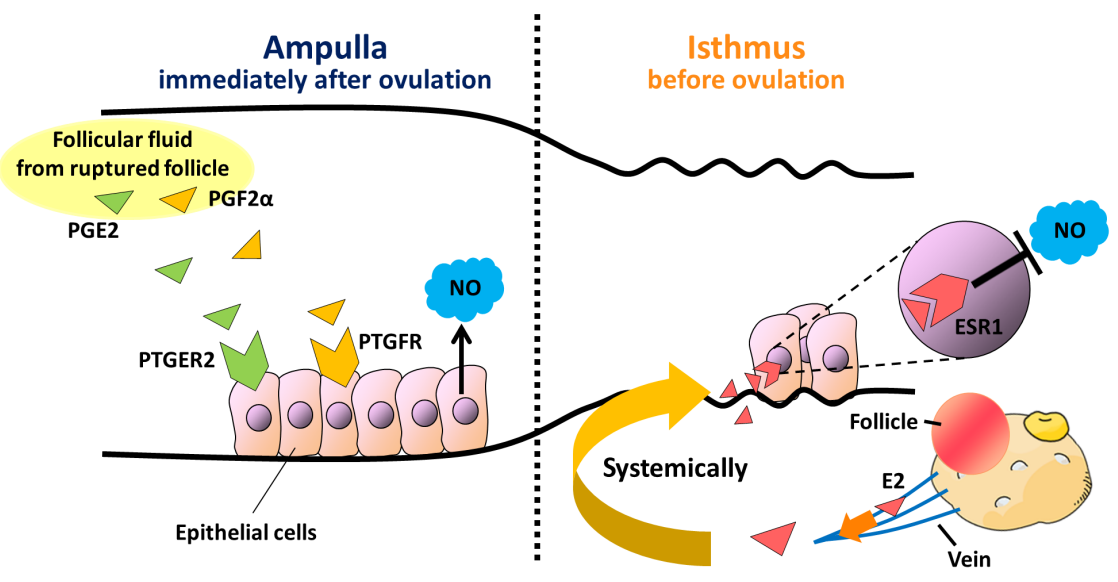

Figure 7 Proposed model to illustrate region-specific regulations of nitric oxide (NO) synthesis in the ampulla and isthmus of the oviduct. Before ovulation, high level of estradiol-17 $\beta$ (E2) released from follicles systemically suppressed NO production by isthmic oviductal epithelial cells via estrogen receptor $\alpha$ (ESR1). Because NO stimulates the motility of spermatozoa (Miraglia et al. 2011), suppressing NO by E2 in the isthmus may contribute to decreasing the motility of spermatozoa and promoting their binding to epithelial cilia until they become hyperactivated. However, prostaglandin (PG), E2, and PGF2 $\alpha$ derived from follicular fluid directly stimulate NO production by ampullary oviductal epithelial cells immediately after ovulation via E-prostanoid receptor type 2 (PTGER2) and F-prostanoid receptor (PTGFR) respectively. Because NO contributes to the survival of oocyte and embryos (Manser et al. 2004, Goud et al. 2005), PGs may play roles in maintaining the optimal concentrations of $\mathrm{NO}$ in the ampulla for the survival of oocyte and embryos.

expressed in both ampullary and isthmic tissues during the estrous cycle (Figs 2A and 3A). ESR1 and PGR proteins were localized in epithelial cells of the ampulla and isthmus of the oviduct (Fig. 2B). PGR protein was detected in smooth muscle layer of the isthmic region (Fig. 2B). PTGER2, PTGER4, and PTGFR proteins were distributed in the epithelium of both regions (Fig. 3B). PTGER2 and PTGFR were also detected in the stromal and smooth muscle layer (Fig. 3B).

\section{Concentrations of ovarian steroids and PGs in follicular fluid immediately before ovulation}

Concentrations of E2, P4, PGE2, and PGF2 $\alpha$ in follicular fluid obtained from cows that were treated to induce super-ovulation were determined. Ranges of concentrations of E2, P4, PGE2, and PGF2 $\alpha$ were 106.3$409.9 \mathrm{nmol} / \mathrm{L}, \quad 771.0-2763 \mathrm{nmol} / \mathrm{L}, \quad 5.68-40.1 \mathrm{nmol} / \mathrm{L}$, and $61.9-835 \mathrm{nmol} / \mathrm{L}$ respectively (Table 1 ).

\section{Effects of estradiol-17ß (E2) or progesterone (P4) on NOS2 $m R N A$ expression}

To determine the regulation of $\mathrm{NO}$ synthesis in the oviduct, we investigated the effects of ovarian steroid hormones (E2 or P4) on NOS2 mRNA expression in cultured oviductal epithelial cells. Estradiol$17 \beta$ suppressed NOS2 mRNA expression and NO production in isthmic epithelial cells after 24-h incubation, but not in ampullary epithelial cells (Fig. 4A). Progesterone stimulated NOS2 mRNA expression after 24 -h incubation but not after 1 - or 4 -h incubations. By contrast, P4 did not affect NOS2 expression in epithelial cells obtained from the isthmus (Fig. 4A). An ESR1 antagonist blocked the inhibiting effect of E2 on NOS2 expression, whereas an ESR2 antagonist did not (Fig. 4B).

\section{Effects of PGs on NOS2 mRNA expression in cultured oviductal epithelial cells}

NOS2 mRNA expression was increased by PGE2 and PGF2 $\alpha$ after 1 -h incubation, whereas NOS2 mRNA expression was decreased after 24-h incubation in ampullary epithelial cells (Fig. 5). However, NOS2 mRNA expression was not affected by PGs in isthmic epithelial cells. A PTGER2 antagonist decreased NOS2 mRNA expression stimulated by PGE2 after 1 -h incubation, whereas a PTGER4 antagonist did not (Fig. 5B).

\section{Differential expression of NOS2 mRNA between the ampulla and isthmus}

In both oviductal tissues and cultured epithelial cells, NOS2 mRNA expression was higher in the ampulla than in the isthmus (Fig. 6).

\section{Discussion}

Nitric oxide (NO), a molecule that has been identified as an endothelium-derived relaxing factor, participates in various physiological events such as the immune response, neurotransmission, and cell proliferation (Bredt \& Snyder 1994, Ignarro et al. 2001). In the oviduct, $\mathrm{NO}$ is also known to relax smooth muscle (Rosselli et al. 1994), and its synthesis is regulated by ovarian hormones during the estrous cycle 
(Lapointe et al. 2006, Ulbrich et al. 2006). The present results suggest that prostaglandins (PGs) in follicular fluid as well as estradiol- $17 \beta$ in blood stream regulate $\mathrm{NO}$ synthesis in oviductal epithelial cells. A model of this regulatory system is shown in Fig. 7 . The oviduct is not only the site where an ovulated oocyte and sperm meet, but it also provides a microenvironment for early embryonic development in the first days of pregnancy (Ulbrich et al. 2010, Ezzati et al. 2014). The present finding that NO synthesis in the ampulla and isthmus was regulated by specific molecules (PGs and E2 respectively) may reflect the idea that the oviduct has region-specific functions. For example, the ampulla serves to transport the oocyte and to provide an environment for fertilization, whereas the isthmus serves to transport spermatozoa and the embryo and to provide an environment for embryo development.

Estradiol-17 $\beta$ concentrations in the oviduct are highest immediately before ovulation (Wijayagunawardane et al. 1998), indicating that a large amount of E2 is transported to the oviduct at the pre-ovulatory stage. In addition, our result showed that ESR1 was highly expressed at the follicular stage in the isthmus (Fig. 2A). These results, together with our finding that $\mathrm{E} 2$ decreased $\mathrm{NO}$ synthesis in cultured isthmic epithelial cells (Fig. 4A), suggest that the E2 transported to the isthmus of the oviduct suppresses NO synthesis via ESR1 at the follicular stage. Spermatozoa entering the oviduct bind to cilia of the oviductal epithelium, which temporarily stops their migration toward the oocyte (Kölle et al. 2009). Because $\mathrm{NO}$ is reported to stimulate the motility of spermatozoa (Miraglia et al. 2011), suppression of $\mathrm{NO}$ synthesis by $\mathrm{E}_{2}$ in the isthmus may decrease the motility of spermatozoa, contributing to their binding to epithelial cilia until they become hyperactivated. We showed that the effects of E2 on NO synthesis were different between ampullary and isthmic epithelial cells. The suppressing effect of E2 on NOS2 mRNA expression was observed only in isthmic epithelial cells despite less expression of ESR1 protein in isthmic tissues than in ampullary tissues (Ulbrich et al. 2003). These different effects of E2 may be involved in the specific characters of epithelial cells in each region of the oviduct. Although oviductal epithelium is composed by two epithelial cells, ciliated and secretory, the isthmic secretory cells interestingly have short kinocilia on the cell surface, but not ampullary secretory cells (Kölle et al. 2009). These differences imply that the secretory cells play specific roles in each region of the oviduct. In fact, NOS2 mRNA expressions in the ampullary tissues and epithelial cells were higher than in the isthmic tissues and epithelial cells respectively (Fig. 6). In addition, partial differences of NO synthases in cyclic epithelium of the oviduct (Ulbrich et al. 2006) and whole layers containing stroma and smooth muscle of the oviduct (Fig. 1) suggest layer-specific control of NO synthesis in the oviductal milieu. Further studies are needed to clarify the region-specific roles of epithelial cells in the oviduct.

The high concentrations of PGE2 and PGF2 $\alpha$ in the follicular fluids by injection of gonadotropinreleasing hormone are consistent with the previous finding that PGE2 and PGF2 $\alpha$ concentrations increase immediately before ovulation, and with the idea that PGs induce follicular rupture (Acosta et al. 1998). After the rupture, the oocyte and follicular fluid containing high concentrations of PGs enters the oviduct. There is evidence that PGs affect NO synthesis in other tissues. For example, PGE2 appears to activate NO synthesis in mouse aortic epithelium (Hristovska et al. 2007), and PGF2 $\alpha$ increases NO production in bovine luteal endothelial cells (Lee et al. 2009). PGE2 and PGF2 $\alpha$ bind to G protein-coupled receptors (GPCRs), named E-prostanoid receptors or F-prostanoid receptor (Gabler et al. 2008, Zhang et al. 2010), inducing rapid signal transductions (Hristovska et al. 2007, Siemieniuch et al. 2009). Therefore, our finding that NOS2 mRNA expression in ampullary epithelial cells increased after 1-h incubation with PGs at concentrations similar to that in follicular fluid (Fig. 5A) suggests that PGs in follicular fluid directly stimulate $\mathrm{NO}$ synthesis in the ampulla, thus controlling the oviductal microenvironment immediately after ovulation. Inhibition of NO synthesis suppresses development of pre-implantation murine embryos in vitro (Manser et al. 2004). NO also delays oocyte aging, suggesting that it has a role in maintaining the quality of oocytes (Goud et al. 2005). Therefore, immediately after ovulation, follicular fluid might have a role in maintaining the optimal concentrations of NO in the oviductal cavity for survival of oocytes and development of embryos. The findings that an NO donor activates ciliary beat frequency in rat oviductal ciliated cells (Chiu et al. 2010) implies that PGs in follicular fluid promote oocyte transport to the site of fertilization via stimulating $\mathrm{NO}$ production immediately after ovulation. In contrast to exposing ampullary oviductal epithelial cells to PGs for $1 \mathrm{~h}$, exposing them to PGs for $24 \mathrm{~h}$ decreased NOS2 mRNA expression (Fig. 5A). This down-regulation of NOS2 may be caused by other molecules that are secreted by PG stimulation. In our unpublished data, a NO donor (NONOate) inhibited NOS2 mRNA expression in ampullary oviductal epithelial cells. Thus, NOS2 expression might be decreased by $\mathrm{NO}$ stimulated by PGs. In contrast to PGs, P4 increased NOS2 expression after 24 -h stimulation in cultured ampullary cells (Fig. 4). Because NO can be involved in both cellular survival and death (Manser et al. 2004, Gotoh \& Mori 2006), NO concentration in the oviductal cavity is possible to be strictly controlled by various molecules derived from inside and outside of the oviduct.

The isthmus is an crucial region of the oviduct for the transport and development of embryos (Ulbrich et al. 2010). A thick smooth muscle layer surrounding 
isthmic mucosa contributes to the waves of contraction and relaxation (Menezo \& Guerin 1997, Hunter 2012), whereas effective transport driven by ciliary beating is not observed in this region (Noreikat et al. 2012). Various molecules regulate the motility of oviductal smooth muscle. Contraction is induced by PGF $2 \alpha$, endothelins, angiotensin II, and E2 (Helm et al. 1982, Wijayagunawardane et al. 2001a,b, Siemieniuch et al. 2009), whereas relaxation is induced by NO, PGE2, luteinizing hormone, and P4 (Helm et al. 1982, Rosselli et al. 1994, Gawronska et al. 1999, Siemieniuch et al. 2009). Some of these molecules are secreted by the oviductal epithelium (Rosselli et al. 1994, Wijayagunawardane et al. 2009, Szóstek et al. 2011), contributing to activate the motility of the oviductal smooth muscle around the time of ovulation. In cattle, the embryo reaches the uterus around 4 days after fertilization (Freeman et al. 1991). Utero-tubal junction is known to strictly contract immediately before the embryo passes through (Croxatto 2002). Thus, the finding in this study that NOS2 expression was highest at days 5-6 after ovulation implies that a large amount of NO produced by isthmic epithelial cells relaxes the isthmus and utero-tubal junction and allows the embryo to enter the uterus. This is supported by the findings that NOS 2 mRNA expression in the isthmic oviduct were highest at day 3.5 of the estrous cycle (Ulbrich et al. 2006). Inhibition of NO synthesis kills morula embryos in vitro (Gouge et al. 1998). As the embryo is considered to reach the uterus at the morula or young blastocyst stage (Hunter 2012), a large amount of $\mathrm{NO}$ produced by isthmic epithelial cells may contribute to embryonic development several days after fertilization.

In conclusion, our results indicate that the regulatory mechanisms of $\mathrm{NO}$ synthesis are different between the ampulla and isthmus of the oviduct. Our results also suggest that PGs in follicular fluid regulate NO synthesis in the ampullary oviductal epithelium. The different regulations of NO synthesis in the ampulla and isthmus might reflect the different roles of these regions during the first days of pregnancy.

\section{Declaration of interest}

The authors declare that there is no conflict of interest that could be perceived as prejudicing the impartiality of the research reported.

\section{Funding}

This work was supported by a Grant-in-Aid for Research Program on Innovative Technologies for Animal Breeding, Reproduction, and Vaccine Development (REP-1002) from the Ministry of Agriculture, Forestry, and Fisheries of Japan. Yoshihiko Kobayashi is a Research Fellow of Japan Society for the Promotion of Science (No. 26924).

\section{Acknowledgements}

The authors are grateful to Dr Seiji Ito (Kansai Medical University, Osaka, Japan) for providing the antiserum of PGE2.

\section{References}

Acosta T, Miyamoto A, Ozawa T, Wijayagunawardane M \& Sato K 1998 Local release of steroid hormones, prostaglandin E2, and endothelin-1 from bovine mature follicles In vitro: effects of luteinizing hormone, endothelin-1, and cytokines. Biology of Reproduction 59 437-443. (doi:10.1095/biolreprod59.2.437)

Acosta T, Ozawa T, Kobayashi S, Hayashi K, Ohtani M, Kraetzl W, Sato K, Schams D \& Miyamoto A 2000 Periovulatory changes in the local release of vasoactive peptides, prostaglandin $F_{2 \alpha^{\prime}}$ and steroid hormones from bovine mature follicles in vivo. Biology of Reproduction 63 1253-1261.

Acosta T, Hayashi K, Ohtani M \& Miyamoto A 2003 Local changes in blood flow within the preovulatory follicle wall and early corpus luteum in cows. Reproduction 125 759-767. (doi:10.1530/rep.0.1250759)

Al-Alem L, Bridges P, Su W, Gong M, Iglarz M \& Ko C 2007 Endothelin-2 induces oviductal contraction via endothelin receptor subtype $A$ in rats. Journal of Endocrinology 193 383-391. (doi:10.1677/JOE-07-0089)

Bredt DS \& Snyder SH 1994 Nitric oxide: a physiologic messenger molecule. Annual Review of Biochemistry 63 175-95. (doi:10.1146/ annurev.bi.63.070194.001135)

Chiu PC, Liao S, Lam KK, Tang F, Ho JC, Ho PC, O WS, Yao YQ \& Yeung WS 2010 Adrenomedullin regulates sperm motility and oviductal ciliary beat via cyclic adenosine 5'-monophosphate/protein kinase $\mathrm{A}$ and nitric oxide. Endocrinology 151 3336-3347. (doi:10.1210/en.2010-0077)

Coleman RA, Smith WL \& Narumiya S 1994 International Union of Pharmacology classification of prostanoid receptors: properties, distribution, and structure of the receptors and their subtypes. Pharmacological Reviews 46 205-229.

Compton DR, Sheng S, Carlson KE, Rebacz NA, Lee IY, Katzenellenbogen BS \& Katzenellenbogen JA 2004 Pyrazolo[1,5-a]pyrimidines: estrogen receptor ligands possessing estrogen receptor $\beta$ antagonist activity. Journal of Medicinal Chemistry 47 5872-5893. (doi:10.1021/jm049631k)

Croxatto H 2002 Physiology of gamete and embryo transport through the fallopian tube. Reproductive BioMedicine Online 4 160-169. (doi:10.1016/S1472-6483(10)61935-9)

Ekerhovd E, Brännström M, Alexandersson M \& Norström A 1997 Evidence for nitric oxide mediation of contractile activity in isolated strips of the human Fallopian tube. Human Reproduction 12 301-305. (doi:10.1093/humrep/12.2.301)

Ekerhovd E, Brännström M, Weijdegård B \& Norström A 1999 Localization of nitric oxide synthase and effects of nitric oxide donors on the human Fallopian tube. Molecular Human Reproduction 5 1040-1047. (doi:10.1093/molehr/5.11.1040)

Ezzati M, Djahanbakhch O, Arian S \& Carr BR 2014 Tubal transport of gametes and embryos: a review of physiology and pathophysiology. Journal of Assisted Reproduction and Genetics 31 1337-1347. (doi:10.1007/s10815-014-0309-x)

Freeman D, Weber J, Geary R \& Woods G 1991 Time of embryo transport through the mare oviduct. Theriogenology 36 823-830. (doi:10.1016/0093-691X(91)90348-H)

Gabler C, Odau S, Muller K, Schon J, Bondzio A \& Einspanier R 2008 Exploring cumulus-oocyte-complex-oviductal cell interactions: gene profiling in the bovine oviduct. Journal of Physiology and Pharmacology 59 (Supplement 9) 29-42.

Gauvreau D, Moisan V, Roy M, Fortier M \& Bilodeau JF 2010 Expression of prostaglandin E synthases in the bovine oviduct. Theriogenology 73 103-111. (doi:10.1016/j.theriogenology.2009.08.006)

Gawronska B, Paukku T, Huhtaniemi I, Wasowicz G \& Ziecik A 1999 Oestrogen-dependent expression of LH/hCG receptors in pig Fallopian tube and their role in relaxation of the oviduct. Journal of Reproduction and Fertility 115 293-301. (doi:10.1530/jrf.0.1150293)

Gotoh T \& Mori M 2006 Nitric oxide and endoplasmic reticulum stress. Arteriosclerosis, Thrombosis, and Vascular Biology 26 1439-1446. (doi:10.1161/01.ATV.0000223900.67024.15)

Goud AP, Goud PT, Diamond MP \& Abu-Soud HM 2005 Nitric oxide delays oocyte aging. Biochemistry 44 11361-11368. (doi:10.1021/bi050711f) 
Gouge R, Marshburn P, Gordon B, Nunley W \& Huet-Hudson Y 1998 Nitric oxide as a regulator of embryonic development. Biology of Reproduction 58 875-879. (doi:10.1095/biolreprod58.4.875)

Halbert S, Tam P \& Blandau R 1976 Egg transport in the rabbit oviduct: the roles of cilia and muscle. Science 191 1052-1053. (doi:10.1126/ science.1251215)

Helm G, Owman C, Sjöberg N \& Walles B 1982 Motor activity of the human Fallopian tube in vitro in relation to plasma concentration of oestradiol and progesterone, and the influence of noradrenaline. Journal of Reproduction and Fertility 64 233-242. (doi:10.1530/jrf.0.0640233)

Hristovska AM, Rasmussen LE, Hansen PBL, Nielsen SS, Nusing RM, Narumiya S, Vanhoutte P, Skott O \& Jensen BL 2007 Prostaglandin E2 induces vascular relaxation by E-prostanoid 4 receptor-mediated activation of endothelial nitric oxide synthase. Hypertension $\mathbf{5 0}$ 525-530. (doi:10.1161/HYPERTENSIONAHA.107.088948)

Hunter R 2012 Components of oviduct physiology in eutherian mammals. Biological Reviews of the Cambridge Philosophical Society 87 244-255. (doi:10.1111/brv.2012.87.issue-1)

Ignarro L, Buga G, Wei L, Bauer P, Wu G \& del Soldato P 2001 Role of the arginine-nitric oxide pathway in the regulation of vascular smooth muscle cell proliferation. PNAS 98 4202-4208. (doi:10.1073/pnas.071054698)

Jeoung M, Lee S, Hawng H-K, Cheon Y-P, Jeong Y, Gye M, Iglarz M, Ko C \& Bridges P 2010 Identification of a novel role for endothelins within the oviduct. Endocrinology 151 2858-2867. (doi:10.1210/en.2009-1155)

Kölle S, Dubielzig S, Reese S, Wehrend A, König P \& Kummer W 2009 Ciliary transport, gamete interaction, and effects of the early embryo in the oviduct: ex vivo analyses using a new digital videomicroscopic system in the cow. Biology of Reproduction 81 267-274. (doi:10.1095/ biolreprod.108.073874)

Kaneko H 1995 Studies on Mechanisms Regulating FSH Secretion in Cattle. Journal of Reproduction and Development 41 113-120. (doi:10.1262/ jrd.95-416j113)

Kobayashi Y, Wakamiya K, Kohka M, Yamamoto Y \& Okuda K 2013 Summer heat stress affects prostaglandin synthesis in the bovine oviduct. Reproduction 146 103-110. (doi:10.1530/REP-12-0479)

Lapointe J, Roy M, St-Pierre I, Kimmins S, Gauvreau D, MacLaren L \& Bilodeau J-F 2006 Hormonal and spatial regulation of nitric oxide synthases (NOS) (neuronal NOS, inducible NOS, and endothelial NOS) in the oviducts. Endocrinology 147 5600-5610. (doi:10.1210/en.20051548)

Lee S-H, Acosta T, Yoshioka S \& Okuda K 2009 Prostaglandin $F_{2 \alpha}$ regulates the nitric oxide generating system in bovine luteal endothelial cells. Journal of Reproduction and Development 55 418-424. (doi:10.1262/ jrd.20205)

Livak K \& Schmittgen T 2001 Analysis of relative gene expression data using real-time quantitative PCR and the $2^{-\Delta \Delta C T}$ method. Methods 25 402-408. (doi:10.1006/meth.2001.1262)

Manser R, Leese H \& Houghton F 2004 Effect of inhibiting nitric oxide production on mouse preimplantation embryo development and metabolism. Biology of Reproduction 71 528-533. (doi:10.1095/ biolreprod.103.025742)

Menezo Y \& Guerin P 1997 The mammalian oviduct: biochemistry and physiology. European Journal of Obstetrics, Gynecology, and Reproductive Biology 73 99-104. (doi:10.1016/S0301-2115(97)027292)

Miraglia E, De Angelis F, Gazzano E, Hassanpour H, Bertagna A, Aldieri E, Revelli A \& Ghigo D 2011 Nitric oxide stimulates human sperm motility via activation of the cyclic GMP/protein kinase G signaling pathway. Reproduction 141 47-54. (doi:10.1530/REP-10-0151)

Miyamoto Y, Skarzynski D \& Okuda K 2000 Is tumor necrosis factor $\alpha$ a trigger for the initiation of endometrial prostaglandin $F_{2 \alpha}$ release at luteolysis in cattle? Biology of Reproduction 62 1109-1115. (doi:10.1095/biolreprod62.5.1109)

Moncada S \& Higgs A 1993 The L-arginine-nitric oxide pathway. New England Journal of Medicine 329 2002-2012. (doi:10.1056/ NEJM199312303292706)

Noreikat K, Wolff M, Kummer W \& Kölle S 2012 Ciliary activity in the oviduct of cycling, pregnant, and muscarinic receptor knockout mice. Biology of Reproduction 86 120. (doi:10.1095/ biolreprod.111.096339)

Okuda K, Kito S, Sumi N \& Sato K 1988 A study of the central cavity in the bovine corpus luteum. Veterinary Record 123 180-183. (doi:10.1136/ vr.123.7.180)
Reeves PR 1978 Distribution, elimination, and residue studies in the cow with the synthetic prostaglandin estrumate. Journal of Agricultural and Food Chemistry 26 152-155. (doi:10.1021/jf60215a001)

Rosselli M, Imthurn B, Macas E, Keller P \& Dubey R 1994 Endogenous nitric oxide modulates endothelin-1 induced contraction of bovine oviduct. Biochemical and Biophysical Research Communications 201 143-148. (doi:10.1006/bbrc.1994.1680)

Saint-Dizier M, Sandra O, Ployart S, Chebrout M \& Constant F 2012 Expression of nuclear progesterone receptor and progesterone receptor membrane components 1 and 2 in the oviduct of cyclic and pregnant cows during the post-ovulation period. Reproductive Biology and Endocrinology 10 76. (doi:10.1186/1477-7827-10-76)

Sakumoto R, Komatsu T, Kasuya E, Saito T \& Okuda K 2006 Expression of mRNAs for interleukin-4, interleukin-6 and their receptors in porcine corpus luteum during the estrous cycle. Domestic Animal Endocrinology 31 246-257. (doi:10.1016/j.domaniend.2005.11.001)

Siemieniuch M, Woclawek-Potocka I, Deptula K, Okuda K \& Skarzynski D 2009 Effects of tumor necrosis factor- $\alpha$ and nitric oxide on prostaglandins secretion by the bovine oviduct differ in the isthmus and ampulla and depend on the phase of the estrous cycle. Experimental Biology and Medicine 234 1056-1066. (doi:10.3181/0901-RM-23)

Suarez S 2008 Regulation of sperm storage and movement in the mammalian oviduct. International Journal of Developmental Biology $\mathbf{5 2}$ 455-462. (doi:10.1387/ijdb.072527ss)

Sun J, Huang YR, Harrington WR, Sheng S, Katzenellenbogen JA \& Katzenellenbogen BS 2002 Antagonists selective for estrogen receptor $\alpha$. Endocrinology 143 941-947. (doi:10.1210/endo.143.3.8704)

Szóstek A, Siemieniuch M, Deptula K, Woclawek-Potocka I, Majewska M, Okuda K \& Skarzynski D 2011 Ovarian steroids modulate tumor necrosis factor- $\alpha$ and nitric oxide-regulated prostaglandin secretion by cultured bovine oviductal epithelial cells. Domestic Animal Endocrinology 41 14-23. (doi:10.1016/j.domaniend.2011.01.007)

Tanikawa M, Acosta T, Fukui T, Murakami S, Korzekwa A, Skarzynski D, Piotrowska K, Park C \& Okuda K 2005 Regulation of prostaglandin synthesis by interleukin- $1 \alpha$ in bovine endometrium during the estrous cycle. Prostaglandins and Other Lipid Mediators 78 279-290. (doi:10.1016/j.prostaglandins.2005.09.003)

Uenoyama Y, Hattori S, Miyake M \& Okuda K 1997 Up-regulation of oxytocin receptors in porcine endometrium by adenosine 3',5'-monophosphate. Biology of Reproduction 57 723-728. (doi:10.1095/biolreprod57.4.723)

Ulbrich S, Kettler A \& Einspanier R 2003 Expression and localization of estrogen receptor $\alpha$, estrogen receptor $\beta$ and progesterone receptor in the bovine oviduct in vivo and in vitro. Journal of Steroid Biochemistry and Molecular Biology 84 279-289. (doi:10.1016/S0960-0760(03)00039-6)

Ulbrich S, Rehfeld S, Bauersachs S, Wolf E, Rottmayer R, Hiendleder S, Vermehren M, Sinowatz F, Meyer H \& Einspanier R 2006 Regionspecific expression of nitric oxide synthases in the bovine oviduct during the oestrous cycle and in vitro. Journal of Endocrinology 188 205-213. (doi:10.1677/joe.1.06526)

Ulbrich S, Zitta K, Hiendleder S \& Wolf E 2010 In vitro systems for intercepting early embryo-maternal cross-talk in the bovine oviduct. Theriogenology 73 802-816. (doi:10.1016/j.theriogenology.2009. 09.036)

Wijayagunawardane M, Miyamoto A, Cerbito W, Acosta T, Takagi M \& Sato K 1998 Local distributions of oviductal estradiol, progesterone, prostaglandins, oxytocin and endothelin-1 in the cyclic cow. Theriogenology 49 607-618. (doi:10.1016/S0093-691X(98)00011-9)

Wijayagunawardane M, Choi Y, Miyamoto A, Kamishita H, Fujimoto S, Takagi M \& Sato K 1999 Effect of ovarian steroids and oxytocin on the production of prostaglandin E2, prostaglandin F $2 \alpha$ and endothelin- 1 from cow oviductal epithelial cell monolayers in vitro. Animal Reproduction Science 56 11-17. (doi:10.1016/S0378-4320(99)00021-4)

Wijayagunawardane $M$, Kodithuwakku S, De Silva N \& Miyamoto A 2009 Angiotensin II secretion by the bovine oviduct is stimulated by luteinizing hormone and ovarian steroids. Journal of Reproduction and Development 55 570-575. (doi:10.1262/jrd.20071)

Wijayagunawardane M, Miyamoto A, Taquahashi Y, Gabler C, Acosta T, Nishimura M, Killian G \& Sato K 2001a In vitro regulation of local secretion and contraction of the bovine oviduct: stimulation by luteinizing hormone, endothelin-1 and prostaglandins, and inhibition by oxytocin. Journal of Endocrinology 168 117-130. (doi:10.1677/ joe.0.1680117) 
Wijayagunawardane MP, Miyamoto A, Taquahashi Y, Acosta TJ, Nishimura M \& Sato K 2001b Angiotensin II and atrial natriuretic peptide in the cow oviductal contraction in vitro: direct effect and local secretion of prostaglandins, endothelin-1, and angiotensin II. Biology of Reproduction 65 799-804. (doi:10.1095/biolreprod65.3.799)

Woodward DF, Pepperl DJ, Burkey TH \& Regan JW 1995 6-Isopropoxy9-oxoxanthene-2-carboxylic acid (AH 6809), a human EP2 receptor antagonist. Biochemical Pharmacology 50 1731-1733. (doi:10.1016/0006-2952(95)02035-7)

Yilmaz O, Całka J, Bukowski R, Zalecki M, Wasowicz K, Jaroszewski J, Markiewicz W, Bulbul A \& Ucar M 2012 Nitric oxide in the bovine oviduct: influence on contractile activity and nitric oxide synthase isoforms localization. Theriogenology 77 1312-1327. (doi:10.1016/j. theriogenology.2011.10.036)

Zhang J, Gong Y \& Yu Y 2010 PG F2 $\alpha$ receptor: A promising therapeutic target for cardiovascular disease. Frontiers in Pharmacology $\mathbf{1} 116$. (doi:10.3389/fphar.2010.00116)

Received 18 November 2015

First decision 8 January 2016

Revised manuscript received 26 February 2016

Accepted 3 March 2016 